\title{
Boosting renewable power generation in Indonesia electricity sector: a policy action by the government
}

\author{
Andy Noorsaman Sommeng ${ }^{1,2}$ and Chrisnawan Anditya ${ }^{1, *}$ \\ ${ }^{1}$ Directorate General of Electricity, Ministry of Energy and Mineral Resources (MEMR) Republic of Indonesia, 12950 Jakarta, \\ Indonesia \\ ${ }^{2}$ Chemical Engineering Departement, Faculty of Engineering, University of Indonesia, 16424 Depok, Indonesia
}

\begin{abstract}
Indonesia is committed to reducing Greenhouse Gas Emissions (GHG) by $29 \%$ against Business as Usual (BAU) projections in 2030 with its own efforts and $41 \%$ with international assistance as part of the Paris Agreement. In the management and utilization of electricity, the development of renewable energy (RE) power generation in Indonesia is carried out while taking into account the balance with other aspects, namely Energy Security, Energy Equity, and Energy Sustainability or called as Energy Trilemma. In accordance with PLN's Electricity Supply and Demand Business Plan (RUPTL) 2018-2027 that has been approved by the Minister of Energy and Mineral Resources, the total capacity of RE power generation to be built up to 2025 is about of $14.3 \mathrm{GW}$ consists of geothermal power generation (PLTP) of 4.6 GW; hydro power generation (including mini-hydro and pump storage): $7.7 \mathrm{GW}$; solar power generation (PLTS): $1.0 \mathrm{GW}$; wind power generation (PLTB): $0.6 \mathrm{GW}$; and biomass/waste power generation (PLTBm/PLTSa): $0.4 \mathrm{GW}$. The RE power generation to be developed is still dominated by "Non-Intermittent" RE power generation (89\%). While the "Intermittent" RE power generation that will be developed is still relatively small, which is only about $11 \%$. This is due to challenges in its development, namely PLN is the only "Off-Taker" in the electricity business, and not all RE power generation can be accepted by the electricity system. As an effort to improve the development of RE power generation, the policy actions that have been or will be implemented by the government are 1) Development of RE power generation should be consider the balancing between "supply and demand" and the readiness of the electricity system to tapping the RE power generation at the most competitive costs; 2) Development of Distributed Generation or Micro-Grid; 3) Revision of the Grid Code to accommodate the Intermittent RE power generator; 4) Development of Smart-Grid; and 5) Acceleration of the Electric Vehicle Program.
\end{abstract}

\section{Introduction}

As a follow up to the World Climate Change Summit (UNFCCC COP21) in Paris in December 2015 where the Paris Agreement was adopted by all countries, Indonesia has committed to reduce Greenhouse Gas Emissions (GHG) by $29 \%$ against Business as Usual (BAU) projections in 2030 with its own efforts and $41 \%$ with international assistance. In the speech of the President of the Republic of Indonesia, it was stated that emissions mitigation in the energy sector was carried out by taking steps to shifting fuel subsidies for productive activities and infrastructure; increase the portion of New Renewable Energy (NRE) to 23\% in the National Energy Mix in 2025; and processing waste for electricity and improving environmental quality [1].

As of the end of 2017, the total installed capacity of national power generation was $60.8 \mathrm{GW}$ where Renewable Energy (RE) generation had only reached 7.3 $\mathrm{GW}$ or only $12 \%$ of the total national power generation installed capacity. Diesel power generations are still dominant in the electricity supply, especially in the Kalimantan electricity system. Sulawesi, Nusa Tenggara, Maluku and Papua. This causes the cost of supply (BPP) of electricity power generation in those electricity *Corresponding author: chrisnawan.anditya@esdm.go.id systems are still be quite high, ranging from 8.33 $\mathrm{USD} / \mathrm{kWh}$ cents in the South, Southeast, West Sulawesi electricity system to $20 \mathrm{USD} / \mathrm{kWh}$ cents in the East Nusa Tenggara electricity system [2]. When looking at the energy mix in power generation managed by PT PLN (Persero) including power generation owned by Independent Power Producers (IPPs), as of the end of 2017 , the RE's share has only reached $13.1 \%$ of the total energy mix of power generation. Fossil energy still dominates energy mix of power generation with share about of $86.9 \%$.

\section{Indonesia's Trilemma of Energy}

In the management and utilization of electricity, the development of renewable energy (RE) power generation in Indonesia is carried out while taking into account the balance with other aspects, namely Energy Security, Energy Equity, and Energy Sustainability or called as Energy Trilemma (Figure 1) [3]. 


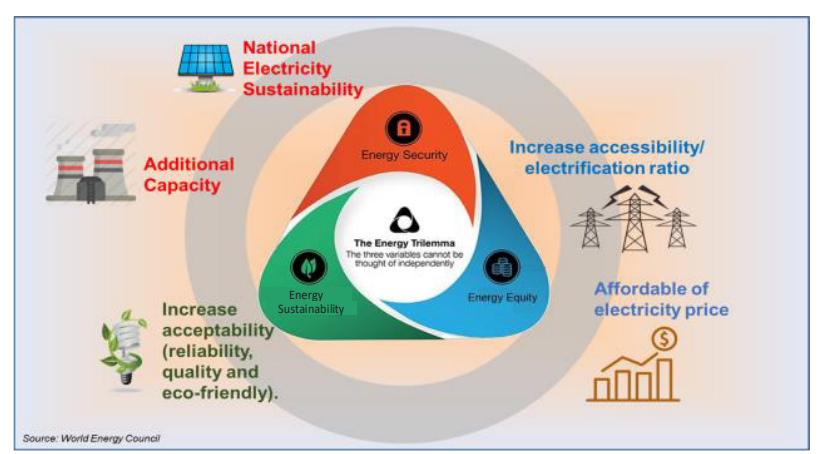

Fig. 1. Energy Trilemma of Indonesia

\subsection{Energy Security}

Energy Security, is how we can create the management of primary energy supplies that we have and energy from outside effectively, maintain the reliability of energy infrastructure and the ability to meet current and future demands. In the electricity sector, Energy Security is realized through the addition of electricity infrastructure which includes power generation, transmission and distribution of electricity to increase electricity availability for the community. One program that is now being run by the government in this regard is the 35,000 MW Program. Although most of the power generation to be developed under this program are fossil-fuelled power generation, but there are also RE power generation to be developed, which are $3.0 \mathrm{GW}$ or around $8 \%$ of the total capacity of 35,000 MW Program. As of the first semester of 2018, the progress of the 35,000 MW program is projects have been operated (COD)/commissioning amounted to $2.61 \mathrm{GW}$; under construction: $17.40 \mathrm{GW}$; having PPA but not yet construction: $12.28 \mathrm{GW}$; under procurement; $2.14 \mathrm{GW}$; and under planning: $1.00 \mathrm{GW}$.

\subsection{Energy Equity}

Energy Equity, is creating accessibility and affordability of electricity supply for the entire community. Improvement of electricity accessibility to the public (accessibility) is carried out by expanding electricity connection for households as indicated by an increase in the electrification ratio, and connection of electricity to villages as indicated by an increase in the ratio of rural electrification. As of the first semester of 2018 , the electrification ratio has reached $97.13 \%$ of the target of $97.50 \%$ and the ratio of rural electrification has reached $97.99 \%$ of the target of $100 \%$. In 2019, the target of the electrification ratio will be $99.90 \%$ and the target of rural electrification ratio will be $100 \%$. Along with the increase in electricity infrastructure and electrification ratio, per capita electricity consumption $(\mathrm{kWh} /$ capita) shows a positive increase.

As of the first semester of 2018, per capita consumption has reached $1,034 \mathrm{kWh} /$ capita from the target of $1,129 \mathrm{kWh} /$ capita, and by 2019 the target for electricity consumption per capita will be 1,200 $\mathrm{kWh} /$ capita. While efforts to create affordable electricity tariff (affordability), the government and the Ministry of Energy and Mineral Resources have determined that electricity tariffs will not increase until 2019. In addition, electricity directed subsidies target to the poor people are still run by the Ministry of Energy and Resources Mineral Power, where the 2019 electricity subsidy policy are as follow:

1. Providing subsidies for poor and susceptive poor households customers with power capacity of 450 VA and 900 VA by referring to the Integrated Data Program for Handling Poor People (DTPPFM),

2. Increasing the national electrification ratio and reducing disparities between regions,

3. Increasing the efficiency of electricity input, among others through reducing oil consumption, and

4. Increase the portion of the use of renewable energy in the energy mix of electricity input.

\subsection{Energy Sustainability}

Energy Sustainability, is to create clean and environmentally friendly energy utilization such as, among others, the development of renewable energy and other low-carbon sources, and efficiency on the supply and demand side. In the electricity sector, energy sustainability is carried out by creating reliable, safe, quality and environmentally friendly infrastructure development. One of the implemented programs is reducing the use of oil in power generation. As of the first semester of 2018, the use of oil in the power generation energy mix managed by PLN was $6.18 \%$ of the target of $5.00 \%$. In 2019 , the target of using oil will be $4.03 \%$. This is done, among others, by accelerating the development of new renewable power generation, increasing gas supply, implementing biodiesel and mine mouth power generation and well-head gas power generators at reasonable prices. In addition to improving the reliability of the electricity system, other efforts were also made was reducing electricity grid losses by increasing supervision to prevent electricity theft and modernizing the system network and metering. As of the first semester of 2018, the losses of electricity network were $9.51 \%$ of the target of $9.6 \%$. The network losses target in 2019 will be $9.40 \%$.

Development of RE power generation is also one of efforts to achieve energy sustainability. However, the implementation of its shall take into account the aspect of affordability to pay of the people. Related to this, the concerned of the Directorate General of Electricity as the regulator of the electricity sector is to keep order the RE developer do not triggering the increasing of cost of power generation, which in turn causes electricity tariffs to the community to be less competitive.

According to the 2017 World Energy Trilemma Index report, Indonesia gets the BCB score (Energy Security: B; Energy Equity: C; and Environmental Sustainability: B) in the implementation of Energy Trilemma, and ranks 75 of the 125 assessed countries. The score was given by the World Bank for the implementation of Energy Trilemma in Indonesia was $\mathrm{BCB}$ is due to fossil fuels is still the dominant energy 
source used in Indonesia to meet the growth of sustainable energy demand with the level of development and distribution of efficient, low-carbon technology, and carbon-free energy is slower (Energy Security); there are still energy subsidies to support social and economic growth (Energy Equity); and there is renewable energy-based micro-grids policies to replace expensive diesel-based power plants gradually in order to accelerate electrification in rural areas (Environmental Sustainability) [4].

\section{Three Trends of the Grid Edge Transformation}

At present, the world of energy including electricity is undergoing to transform due to rapid technology developments and the existence of new innovations has changed the traditional electricity system that we know so far, which has only focused on power generation, transmission and distribution has been transformed into a new electricity system, which is self-system beyond the electricity meter. The three main trends that will support each other and will change the electricity system that we know today, are Electrification, Decentralization, and Digitalization [5] (Figure 2).

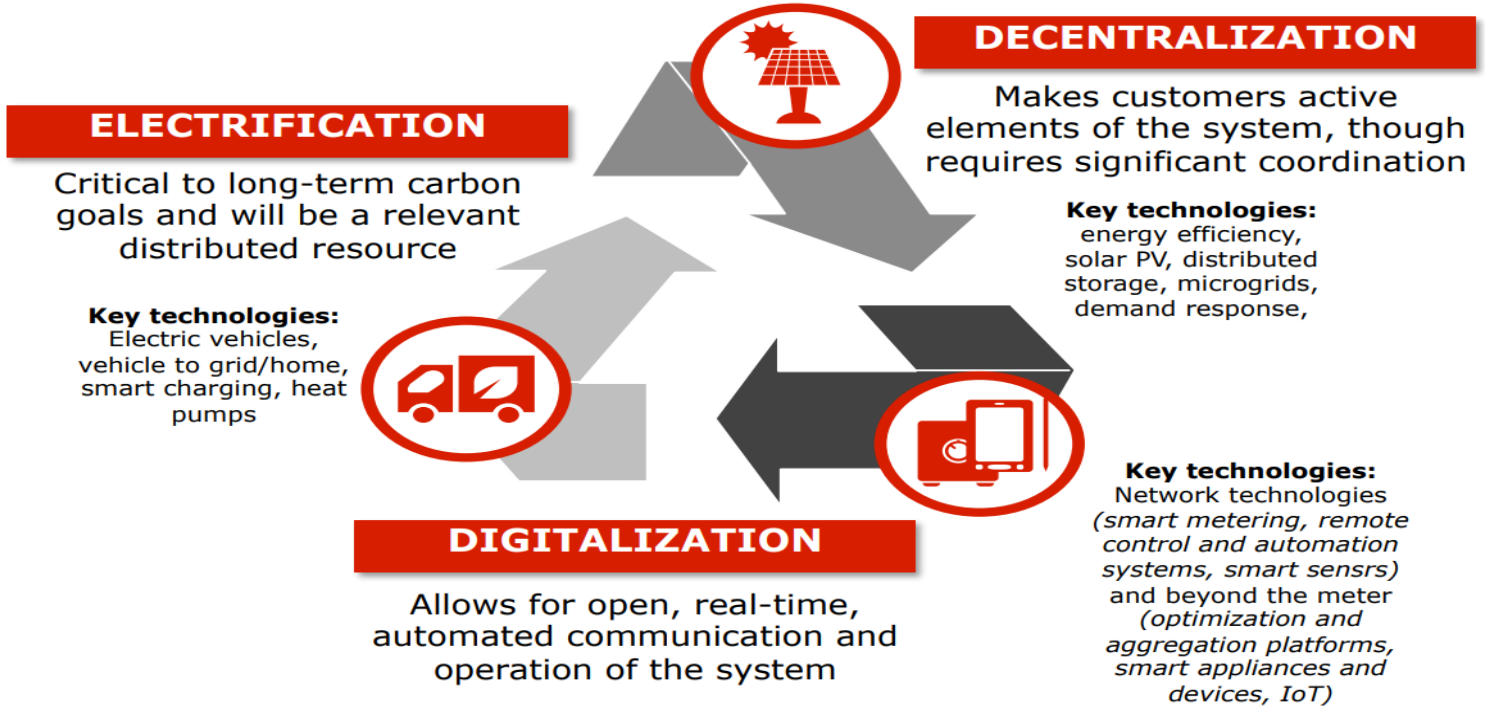

Source : World Economic Forum 2017: The Future of Electricity New Technologies Transforming the Grid Edge

Fig. 2. Three "Grid Edge" Transformation Trends [5]

Distributed Energy Resources (DER) or Distributed Generation systems will grow rapidly as the cost of solar PV decrease and solar PV efficiency increase and storage encourages the arise of renewable energy-based micro-grids to meet future demand for electricity. (Decentralization). Based on IRENA report, in 2017, the rate of cost reduction has been wholly impressive. Solar photovoltaic (PV) modules are more than $80 \%$ cheaper than in 2009. The cost of electricity from solar PV fell by almost three-quarters in 2010-2017 and continuous decline. [6] The cost of utility-scale solar PV technology has fallen by $80 \%$ in 2016 when compared to the cost of the technology in 2008 [7]. Along with the easier and the availability of electricity, the use of electricity for other purposes such as transportation and heating will increase public electricity consumption (Electrification). This encourages people to be able to meet their own electricity needs and enable the community to exchange energy or services between them with the support of smart-meter. The advance of Internet of Things (IoT) technology allows every electricity load to have "identity" and electricity usage log (big data) so that electricity use is more efficient when RE power generation and energy storage technologies can be integrated with electricity user behaviour (Digitalization). This technology trend will then change the electricity system in the future, where the community that is only been as consumers, has transformed not only as consumers but can become producers or called as "Proconsumer". This condition encouraged the emerge of Electricity 4.0. 


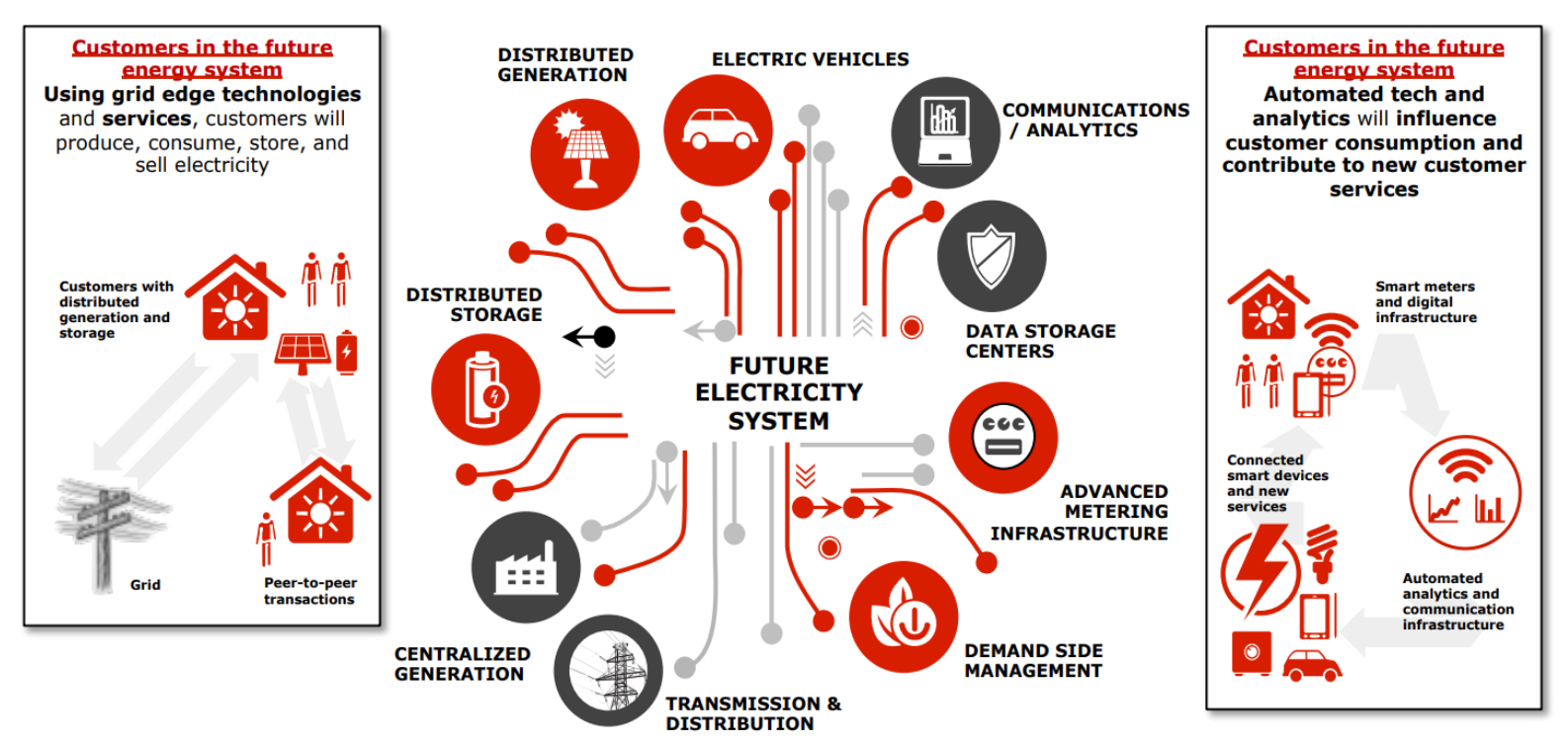

Source : World Economic Forum 2017: The Future of Electricity New Technologies Transforming the Grid Edge

Fig. 3. Future Energy System [5]

The development of the three technology trends is predicted to increase from year to year, where the leap of the technology will increase sharply around 2025 (tipping point), and further develop rapidly follows the existing technologies, such as telephone, radio, refrigerator and TV to achieve $80 \%$ market penetration (Figure 4).

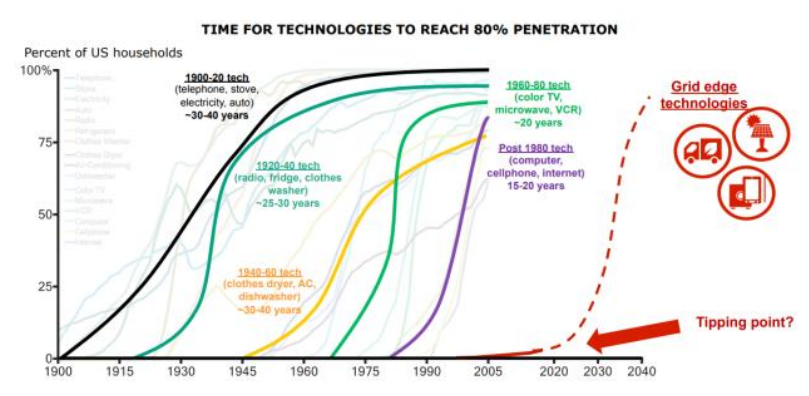

Fig. 4. The Development of The Three Technology Trends[5]
There are several requirements that need to be done so that the transformation of the three technology trends (electrification, decentralization, and digitalization) from the current condition to the future can run smoothly (Figure 5.), namely 1). Change the rules of the game, advancing and reforming regulation to enable new roles for distribution network operators, innovation and full integration of distributed energy resources (regulatory paradigm redesign); 2). Ensure timely deployment of the infrastructure to enable new business models and the future energy system; 3 ). Incorporate the new reality of a digital, customer empowered, interactive electricity system facilitating customer engagement by making the experience easier, convenient and economical (redefine customer experience); and 4) Pursue new revenue sources from innovative distribution and retail services, and develop business models to adapt to the Fourth Industrial Revolution (embrace new business models). 

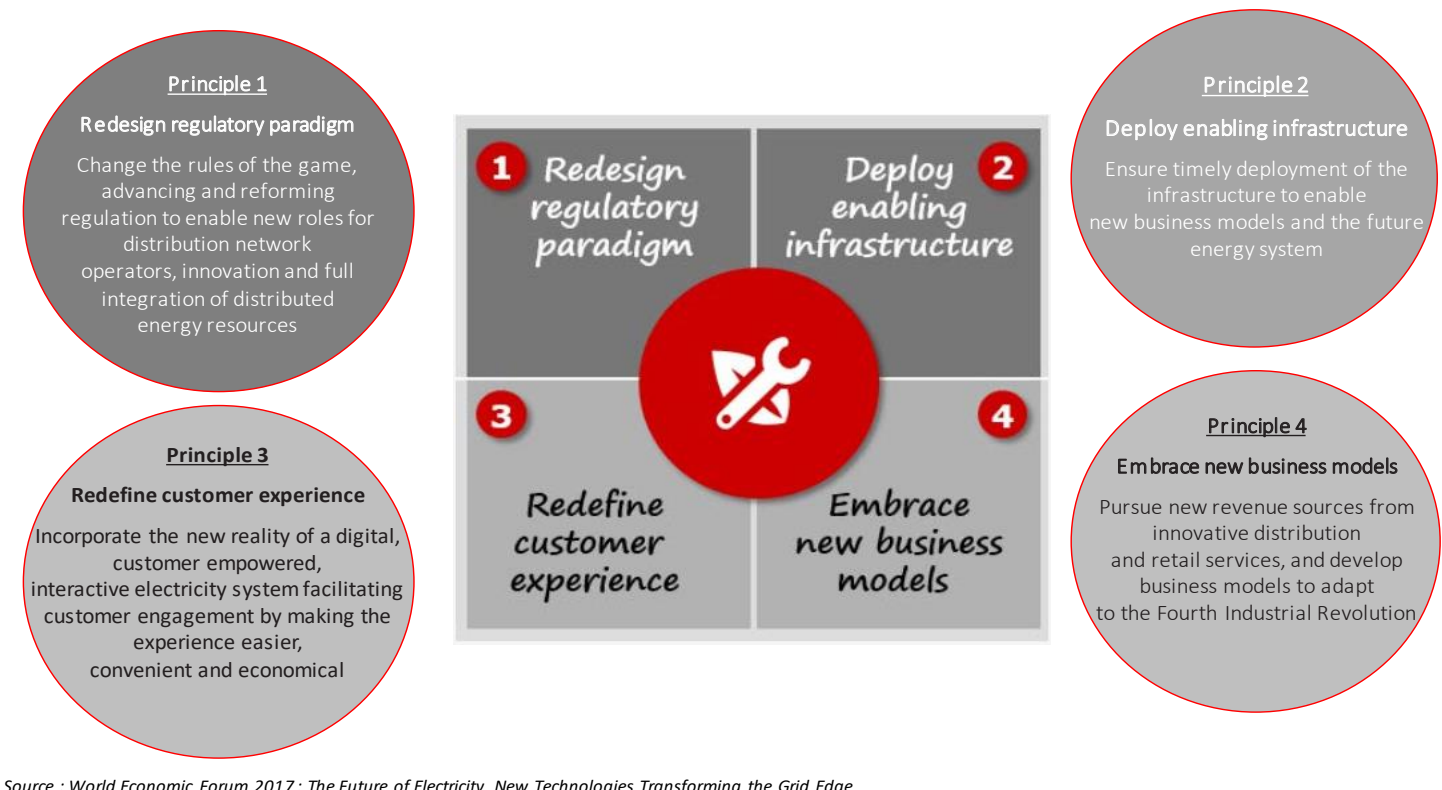

Source : World Economic Forum 2017: The Future of Electricity New Technologies Transforming the Grid Edge

Fig. 5. Grid Edge Actionable Framework [5]

\section{Development Plan of RE Power Generation}

The development of RE power generation in Indonesia in order to meet the electricity needs of the community is always being improved and it is one of the policy directions of national power generation development according to draft of the 2018-2037 National Electricity General Plan (RUKN). Based on this RUKN, the target of the NRE in the power generation energy mix is at least $23 \%$ by 2025 [8]. The efforts to increase RE power generation in the electricity sector is also to aim the achievement of the target of NRE in the primary energy $\operatorname{mix}$ to $23 \%$ by 2025 , as mandated in the National Energy Policy (KEN) [6], and to fulfil Indonesia's commitment in the Paris Agreement.

Based on the PLN's Electricity Supply Demand Business Plan (RUPTL) 2018-2027 that has been approved by the Minister of Energy and Mineral Resources under the Ministerial Decree Number 1567 $\mathrm{K} / 21 / \mathrm{MEM} / 2018$, the total capacity of RE power generation to be built up to 2025 is about of $14.3 \mathrm{GW}$
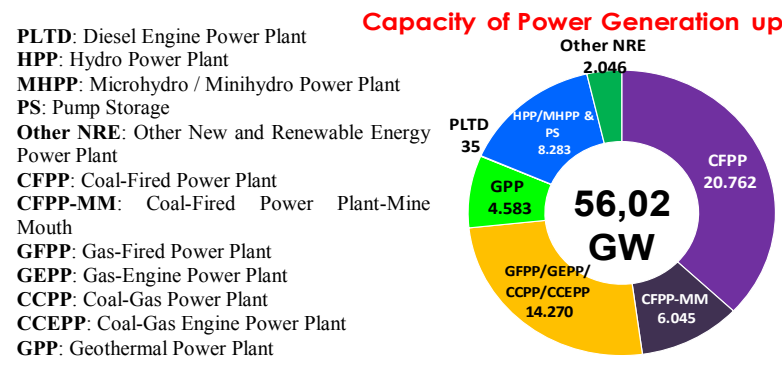

consists of geothermal power generation (PLTP) of 4.6 $\mathrm{GW}$; hydro power generation (including mini-hydro and pump storage): $7.7 \mathrm{GW}$; solar power generation (PLTS): $1.0 \mathrm{GW}$; wind power generation (PLTB): $0.6 \mathrm{GW}$; and biomass/waste power generation (PLTBm/PLTSa): 0.4 GW. The RE power generation to be developed is still dominated by "Non-Intermittent" RE power generation (89\%). While the "Intermittent" RE power generation that will be developed is still relatively small, which is only about $11 \%$. This is due to challenges in its development. The development of RE power generation will increase up to 2027, where the total capacity of RE power generation to be built will be $14.9 \mathrm{GW}$ or an increase of $0.6 \mathrm{GW}$ compared to 2025 (Figure 6) [7].

The development of RE power generation of 14.3 GW by 2025 provides an RE's portion in the power generation energy mix to $23 \%$ in 2025 . The portion of $\mathrm{RE}$ mix in the power generation at least has met the NRE target sets in the draft RUKN 2018-2037 [8], but still not able to meet the NRE portion target as stated in the National Energy Policy (KEN) [6].

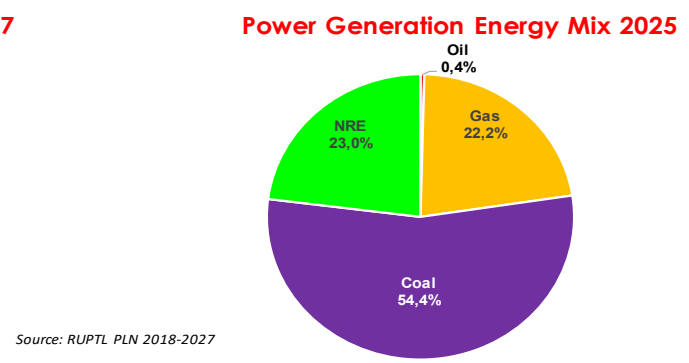

Fig. 6. Capacity of Indonesia's Power Generation up to 2027 and Target of Energy Mix for Indonesia's Power Generation in 2025[7] 
Table 1. Plan of New and Renewable Energy Power Generation Development 2018 - 2027 [7]

\begin{tabular}{|c|c|c|c|c|c|c|c|c|c|c|c|c|c|}
\hline No & $\begin{array}{l}\text { Renewable } \\
\text { Energy } \\
\text { Power } \\
\text { Generation }\end{array}$ & Capacity & 2018 & 2019 & 2020 & 2021 & 2022 & 2023 & 2024 & 2025 & 2026 & 2027 & Total \\
\hline 1 & Geothermal & MW & 210 & 150 & 221 & 235 & 405 & 445 & 365 & 2,527 & 20 & 5 & 4,583 \\
\hline 2 & $\begin{array}{c}\text { Hydro } \\
\text { Power }(\geq \\
10 \mathrm{MW} \\
\text { Installed } \\
\text { Capacity } \\
\text { per Unit) }\end{array}$ & MW & 66 & 287 & 193 & 755 & 315 & 196 & 635 & 4,461 & - & 564 & 7,472 \\
\hline 3 & $\begin{array}{c}\text { Minihydro } \\
/ \\
\text { Microhydro } \\
\text { (<10 MW } \\
\text { Installed } \\
\text { Capacity } \\
\text { per Unit) }\end{array}$ & MW & 108 & 202 & 366 & 103 & 31 & - & - & - & - & - & 811 \\
\hline 4 & Solar & $\mathrm{MW}_{\mathrm{P}}$ & 5 & 22 & 214 & 281 & - & 200 & - & 325 & - & - & 1,047 \\
\hline 5 & Wind & MW & 70 & 60 & 5 & 45 & 10 & 30 & 309 & - & - & 60 & 589 \\
\hline 6 & Biomass & MW & 53 & 53 & 41 & 19 & 235 & - & - & - & - & 10 & 411 \\
\hline 7 & $\begin{array}{c}\text { Ocean } \\
\text { Current }\end{array}$ & MW & - & - & - & - & - & - & - & - & - & - & - \\
\hline 8 & Biofuel & $\begin{array}{l}\text { Thousand } \\
\text { Kiloliters }\end{array}$ & 607 & 598 & 375 & 217 & 146 & 150 & 154 & 157 & 165 & 176 & 2,745 \\
\hline & Total & MW & 512 & 774 & 1,040 & 1,438 & 996 & 871 & 1,309 & 7,313 & 20 & 639 & 14,912 \\
\hline
\end{tabular}

Table 2. Composition of Energy Mix for Indonesia's Power Generation [7]

\begin{tabular}{|c|c|c|c|c|c|c|c|c|c|c|c|}
\hline No & $\begin{array}{c}\text { Type of Fuel for } \\
\text { Indonesia's Power } \\
\text { Generation }\end{array}$ & 2018 & 2019 & 2020 & 2021 & 2022 & 2023 & 2024 & 2025 & 2026 & 2027 \\
\hline 1 & Hydro & $6.9 \%$ & $6.0 \%$ & $5.7 \%$ & $5.8 \%$ & $5.5 \%$ & $6.2 \%$ & $6.8 \%$ & $9.9 \%$ & $9.5 \%$ & $9.3 \%$ \\
\hline 2 & Geothermal & $5.4 \%$ & $5.6 \%$ & $5.5 \%$ & $5.7 \%$ & $6.2 \%$ & $6.2 \%$ & $6.4 \%$ & $11.7 \%$ & $10.7 \%$ & $9.8 \%$ \\
\hline 3 & $\begin{array}{c}\text { Other New and } \\
\text { Renewable Energy }\end{array}$ & $0.2 \%$ & $0.8 \%$ & $0.9 \%$ & $0.9 \%$ & $0.9 \%$ & $0.8 \%$ & $0.9 \%$ & $1.5 \%$ & $1.4 \%$ & $1.3 \%$ \\
\hline 4 & Gas & $20.8 \%$ & $23.2 \%$ & $24.0 \%$ & $21.6 \%$ & $22.1 \%$ & $21.8 \%$ & $20.9 \%$ & $22.2 \%$ & $21.1 \%$ & $20.6 \%$ \\
\hline 5 & Oil & $4.2 \%$ & $3.9 \%$ & $2.2 \%$ & $1.1 \%$ & $0.5 \%$ & $0.4 \%$ & $0.4 \%$ & $0.4 \%$ & $0.4 \%$ & $0.4 \%$ \\
\hline 6 & Coal & $62.0 \%$ & $60.0 \%$ & $61.3 \%$ & $64.7 \%$ & $64.8 \%$ & $64.6 \%$ & $64.6 \%$ & $54.4 \%$ & $56.8 \%$ & $58.6 \%$ \\
\hline 7 & Import & $0.5 \%$ & $0.5 \%$ & $0.3 \%$ & $0.2 \%$ & $0.0 \%$ & $0.0 \%$ & $0.0 \%$ & $0.0 \%$ & $0.0 \%$ & $0.0 \%$ \\
\hline & Total & $100 \%$ & $100 \%$ & $100 \%$ & $100 \%$ & $100 \%$ & $100 \%$ & $100 \%$ & $100 \%$ & $100 \%$ & $100 \%$ \\
\hline
\end{tabular}

\section{Challenges in Developing RE Power Generation in Indonesia}

Some challenges in developing RE power generation in Indonesia among others are:

\subsection{PLN is the only "Off-Taker" of electricity business}

The current structure of the electricity industry in Indonesia is "Vertically Integrated Utility plus IPP". It means that the supply of electricity starting from power generation, transmission, distribution and electricity sales to the public is carried out by one utility, namely PT PLN (Persero) - State Owned Electricity Company, which acts as "Off-Taker" of electricity business. The competition that is applied is the "Basic" level, that is, *Corresponding author: chrisnawan.anditya@esdm.go.id the competition is only happen in the power generation side through private power generation (IPP). In the structure of the electricity industry in this model, IPP builds, owns and operates power plants and sells electricity at a determined price to PLN in accordance with the PPA for a relatively long period (maximum 30 years). So that, the regulator must be able to maintain the interests of RE developers as "Sellers", PLN as "Buyers", and the public as "Customers" in a balanced manner in the development of RE power generation in Indonesia.

\subsection{Not all RE power generation can be accepted by the electricity system}

Nothing that PLN is the only "Off-Taker" in the electricity business, then most all RE power generation built by IPP want their electricity production to be 
purchased by PLN. So that the RE power generation must be able to enter the PLN's electricity system. This makes it difficult for some electricity systems, especially for RE power generation that has "Intermittent" properties, namely:

1. As a result of Indonesia's electricity industry structure still being "regulated-market", "planning code" is still not specifically regulated, and system planning is only based on PLN's proposal by looking at the trend of electricity demand and has not emphasized consideration to develop flexible power plants for receiving "Intermittent" RE power generation, one of which is the obligation to contract power generation capacity with a capacity factor (CF) of $80 \%$, so that the flexibility of operating the electricity system is less optimal.

2. The entry of Intermittent RE power generation (solar and wind) in the electricity system requires the availability of a "flexible" power generation or "load follower" power generation to anticipate the loss of power from the Intermittent RE power generation in the electricity system. So that the availability of an ideal reserve (spinning reserve) requires the readiness of PLN's power generation operations at any time resulting in increased PLN operating costs.

3. Not all electricity transmissions owned by PLN have "SCADA", making it difficult for the operation of the electricity system if there is an Intermittent RE power generation. While an Intermittent RE power generation is potentially producing harmonics, voltage variations and transient effect to the grid. Currently, the electricity system that is the most readied to accept the Intermittent $\mathrm{RE}$ power generation is the Java Bali electricity system.

4. The system is difficult to accept the Intermittent RE power generation because of "Over Supply" reasons, especially for electricity systems that have thermal IPP power generation (CFPP and GFPP). Simply because the penetration of the RE power generation from the solar power generation or wind power generation will make the thermal power generation must reduce its output amid the "Take or Pay Clause" condition. Under this condition, PLN must pay penalties to the developer of the thermal IPP power generation if the electricity produced by the thermal IPP power generation cannot be tapped according to the agreed PPA by both parties.

5. Some electricity systems of PLN have a small installed capacity so that the Intermittent RE power generation (solar and wind) only get a small "MW" portion or quota.

\section{Policy Action to Accelerate Power Generation Development}

RE

As an effort to encourage the development of RE power generation, including Intermittent RE power generation in Indonesia, so that the balance of "Energy Trilemma" is maintained, the policy actions that have been implemented and are being implemented by the Directorate General of Electricity, among others are:

\subsection{Development of RE power generation should be consider the balance between "supply and demand" and the readiness of the electricity system to tapping the RE power generation at the most competitive costs.}

This effort is carried out by requiring PLN to buy electricity from RE power generation and requires PLN to openly inform the condition of the local electricity system that is ready to receive RE power generation. All of these policies have been set forth in the Regulation of the Minister of Energy and Mineral Resources Number 50 year 2017 concerning Utilization of Renewable Energy Sources for Electricity Supply [9]. As for maintaining the price of electricity between "Seller" and "Buyer" to be carried out in a balanced manner, the determination of the maximum amount of electricity purchase price by PLN is determined by the Minister of Energy and Mineral Resources by paying attention to the cost of power generation (BPP) in the local electricity system versus the average of National BPP. While the construction of the electricity network for the evacuation of the power of the RE power generation to the connection point of PLN is carried out based on a mutually beneficial mechanism (business to business). The update of BPP in the local electricity system and the average of National BPP is in 2017 as stipulated in the Ministerial Decree of Energy and Mineral Resources Number $1772 \mathrm{~K} / 20 / \mathrm{MEM} / 2018$ concerning the Cost Level of PLN's power generation in 2017 [2].

\subsection{Development of Distributed Generation or Micro-Grid}

The development of Distributed Generation or MicroGrid is currently focused on accelerating electrification in Indonesia rural area that can be developed by all parties by prioritizing the use of RE resources as an energy source for electricity supply. The total capacity of the system that can be developed is a maximum of 50 MW in a limited business area which is given by the Minister of Energy and Mineral Resources as part of to protect the party business. The development regulation of Distributed Generation or Micro-Grid has been stipulated by the government based on the Ministerial Regulation of Energy and Mineral Resources Number 38 year 2016 concerning Acceleration of Electrification in Rural in the area of Undeveloped, Remote, Border, and Small Islands Populated through the Implementation of Electricity Supply for Small Scale [10].

\subsection{Revision of the Grid Code to accommodate the Intermittent RE power generator}

The Intermittent RE power generation is increasingly being developed not only to meet the needs of electricity but also to guarantee the energy security and energy 
sustainability in order to reduce greenhouse gas (GHG) emissions. The first largest wind-farm power generation in Indonesia, the Sidrap $75 \mathrm{MW}$ has been operating in the South, Southeast and West Sulawesi (Sulselrabar) electricity system and is soon followed by a $60 \mathrm{MW}$ Jeneponto wind-farm power generation. Up to 2027, the total capacity of Intermittent RE power generation to be built will be at $1.6 \mathrm{GW}$, which consists of solar power generation of $1.0 \mathrm{GW}$ and wind power generation of 0.6 GW. The current existing Grid Code only accommodates "Non-Intermittent" RE power generation and does not accommodate the development and utilization of Intermittent RE power generation. The case of the Sidrap wind-farm power generation and Jeneponto wind-farm power generation in the Sulselrabar electricity system encouraged the need for revisions of the Grid Code.

Some of the issues discussed in the Grid Code revision included flexibility by requiring the use of Automatic Dispatch Control (ADC)/SCADA and the obligation of power generation entering the electricity system using Automatic Generation Control (AGC) as part of maintaining system flexibility.

\subsection{Development of Smart-Grid}

The implementation of smart-grids in power generation, transmission, substations, distribution, and electricity customers is part of improving the quality and reliability of electricity, efficiency, and enabling the integration of $\mathrm{RE}$ power generation. In accordance with the draft RUKN 2018-2037, the policy direction of smart-grid development is that smart-grid has begun to be implemented in several regions in Java Bali by 2020 and gradually applied to systems outside Java-Bali to encourage RE portion [8]. There are currently 7 smartgrid pilot projects in Indonesia, namely Smart Community Project at Surya Cipta Sarana Industrial Park (collaboration between PLN, Ministry of Energy and Mineral Resources and NEDO); Smart Micro-Grid System on West Sumba Island (collaboration between PLN, BPPT and NTT Regional Government); Bali Eco Smart-Grid for the development of the AMI system with RF communication; Batam Electricity System for the development of Distribution Automation System and AMI; Bangka \& Belitung Electricity System to improve reliability and RE; Kupang Electricity System for the integration of Intermittent RE power generation with existing systems; and other Remote Island Electricity Systems for the basic design of the existing electricity system integration.

\subsection{Acceleration of the Electric Vehicle Program}

Along with the improving electricity conditions in Indonesia and the increasing electrification ratio, the electricity demand for other purposes will be increasingly developed, one of which is electricity for transportation (electrification).

As an effort to reduce fuel dependence, reduce carbon emissions and improve local air quality, the government encourages the use of electric vehicles for land transportation. Currently, the Presidential Regulation on Electric Vehicles is being finalized.

As of June 2018, the total public electricity charging station (SPLU) that has been built by PLN were 1,980. Along with the development of three "Grid Edge" trends where decentralization is one of the "key driver factors", then this action needs to be prepared early by all parties, including the Directorate General of Electricity.

\section{Conclusion}

The Directorate General of Electricity as the regulator in the electricity sector is committed to encouraging increasing RE power generation development in the electricity sector while maintaining the principle of "Energy Trilemma" balance and making policies and regulations conducive by involving the participation of all stakeholders to accommodate all the potential available primary energy to be developed for sustainability of electricity supply.

\section{References}

1. "Statement The President of The Republic of Indonesia H.E. Joko Widodo at Leader's Event 21th Conference of The Parties to The UNFCCC Paris, France, 30 November 2015,” 2015. [Online]. Available: https://unfccc.int/sites/default/files/cop21 cmp11 leaders_event_indonesia.pdf. [Accessed: 26$\bar{A} u g-2018]$.

2. Ministry of Energy and Mineral Resources Republic of Indonesia, "The Minister Decree of Energy and Mineral Resources Republic of Indonesia No. $1772 \mathrm{~K} / 20 / \mathrm{MEM} / 2018$ : PT PLN (Persero) Cost of Power Generation in 2017," 2018. [Online]. Available: http://jdih.esdm.go.id/peraturan/Kepmen-esdm1772-Thn 2018.pdf. [Accessed: 26-Aug-2018].

3. World Energy Council, "World Energy Trilemma 2017: Changing Dynamics - Using Distributed Energy Resources to Meet The Trilemma Challanges (in Partnership with Oliver Wyman)," 2017. [Online]. Available: https://www.mmc.com/content/dam/mmcweb/Global-Risk-Center/Files/2017-energytrilemma-report.pdf. [Accessed: 26-Aug-2018].

4. World Energy Council, "World Energy Trilemma Index 2017: Monitoring The Sustainability of National Energy Systems (in Partnership with Oliver Wyman)," 2017. [Online]. Available: https://www.worldenergy.org/wpcontent/uploads/2017/11/Energy-TrilemmaIndex-2017-Report.pdf. [Accessed: 26-Aug2018].

5. World Economic Forum, "The Future of Electricity: New Technologies Transforming the Grid Edge (In Collaboration with Bain \& Company)," 2017. [Online]. Available: 
http://www3.weforum.org/docs/WEF_Future_of Electricity_2017.pdf. [Accessed: 06-Aug2018].

6. National Energy Council (DEN), “Indonesia's Government Regulation No 79/2014: National Energy Policy (KEN)," 2014. [Online]. Available:

https://www.den.go.id/index.php/publikasi/down load/31. [Accessed: 26-Aug-2018].

7. Ministry of Energy and Mineral Resources Republic of Indonesia, "The Minister Decree of Energy and Mineral Resources Republic of Indonesia No. 1567 K/21/MEM/2018: PLN's Electricity and Supply Business Plan 2018 2027 (RUPTL PT PLN (Persero) 2018 - 2027)," 2018. [Online]. Available: http://www.djk.esdm.go.id/pdf/RUPTL/Salinan Sesuai Aslinya_Kepmen ESDM ttg Pengesahan RUPTL PT PLN (Persero) 2018-2027.pdf. [Accessed: 28-Sep-2018].

8. Ministry of Energy and Mineral Resources Republic of Indonesia, "Draft National Electricity General Plan (RUKN) 2018 - 2037," 2018. [Online]. Available:
http://www.djk.esdm.go.id/pdf/Draft RUKN/Draft RUKN 2018-2037.pdf. [Accessed: 26-Aug-2018].

9. Ministry of Energy and Mineral Resources Republic of Indonesia, "The Minister Regulation of Energy and Mineral Resources Republic of Indonesia No 50/2017: Utilization of Renewable Energy Sources for Electricity Supply," 2017. [Online]. Available: http://jdih.esdm.go.id/peraturan/PerMen ESDM NO. 50 TAHUN 2017.pdf. [Accessed: 26-Aug2018].

10. Ministry of Energy and Mineral Resources Republic of Indonesia, "The Minister Regulation of Energy and Mineral Resources Republic of Indonesia No 38/2016: Acceleration of Electrification in Rural in the area of Undeveloped, Remote, Border, and Small Islands Populated through the Implementation of Electricity Supply for," 2016. [Online]. Available: http://jdih.esdm.go.id/peraturan/Permen ESDM No. 38 Tahun 2016.pdf. [Accessed: 26-Aug2018]. 